\title{
First records of the Dendroxena quadrimaculata (Scopoli, 1771) (Coleoptera, Silphidae) in Tyumen region and possible reasons for its range expansion in Western Siberia
}

\author{
Vitaly A. Stolbov', Elena V. Sergeeva ${ }^{2}$ \\ I Tyumen State University, 6 Volodarskogo St, Tyumen 625003, Russia. \\ 2 Tobolsk Complex Research Station, Ural Branch of the Russian Academy of Science, 15 Acad. Yu. Osi- \\ pova St, Tobolsk 626152, Russia. \\ Corresponding author: Vitaly Stolbov (vitusstgu@mail.ru)
}

Academic editor: A. Matsyura | Received 10 March 2020 | Accepted 12 April 2020 | Published 6 October 2020

http://zoobank.org/EA17C825-6EDA-47A7-81D2-C5E9322BDED2

Citation: Stolbov VA, Sergeeva EV (2020) First records of the Dendroxena quadrimaculata (Scopoli, 1771) (Coleoptera, Silphidae) in Tyumen region and possible reasons for its range expansion in Western Siberia. Acta Biologica Sibirica 6: 369-374. https://doi.org/10.3897/abs.6.e53528

\begin{abstract}
The paper presents data on the first records of Dendroxena quadrimaculata (Scopoli, 1771) in the Tyumen region. D. quadrimaculata is distributed in the European part of Russia, Caucasus and south of Siberia. This species was not previously recorded in the Tyumen region, but within two years (2018-2019), it spread throughout the region. We considered the possible reasons for its range expansion in Western Siberia.
\end{abstract}

\section{Keywords}

Dendroxena quadrimaculata, Western Siberia, new records, climate change

\section{Introduction}

Dendroxena quadrimaculata (Scopoli, 1771) is a Western Palearctic species of Silphidae family and distributed in Central and Southern Europe, Turkey, Iran and Kazakhstan (Rǔžička 2015), acclimatized in Northern Africa (Algeria) and Northern America (Nikolaev and Kozminykh 2002). In Russia, this species is widespread in the 
European part and Caucasus. In the Middle Urals it was recorded in the Perm Krai and Sverdlovsk region (Redikortsev 1908; Kozminykh 1997). In the south of Siberia this species were found in the Krasnoyarsk Krai (Loshchev 2015), Kemerovo Oblast (Efimov 2008) and the Baikal region (Berlov 1977; Pleshanov and Takhteev 2008).

D. quadrimaculata is nemoral forest species. Its imagoes and larvae feed mainly on butterfly caterpillars (Nikolaev and Kozminykh 2002) and therefore this species is used in forest pest control (Ivantsova and Vostrikova 2015). In a number of regions (Vladimir, Kaliningrad, Tver, Tula regions, and Republic of Mordovia), this species is rare and listed in regional Red Data Books.

Earlier, the species was not recorded in the Tyumen region, but within two years (2018-2019), it spread throughout the region from the forest-steppe zone to the southern taiga, where it was found in mixed and birch forests.

\section{Material and methods}

Below is the detailed information about new records in the Tyumen region.

\section{Family Silphidae Latreille, 1806 \\ Subfamily Silphinae Latreille, 1806}

\section{Dendroxena quadrimaculata (Scopoli, 1771)}

Material. Russia - Tyumen region $\bullet 1 \hat{\jmath}, 1+$ (in copuli); Nizhnetavdinsky district, vicinity of biological station of the Tyumen State University "Lake Kuchak";

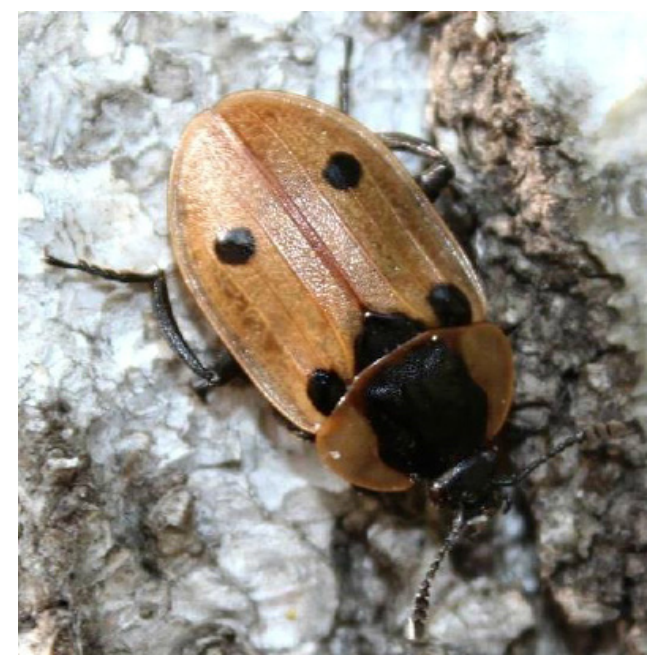

Figure I. Imago (Tobolsky distr.). 


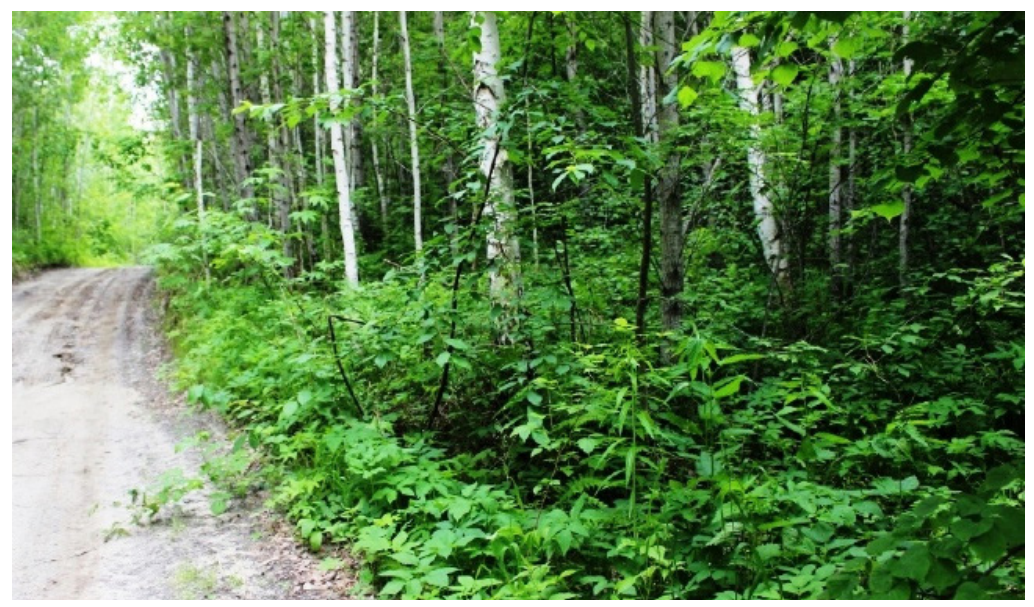

Figure 2. Mixed forest in the south taiga (Tobolsky distr.).

$57^{\circ} 20^{\prime} 44^{\prime \prime} \mathrm{N}, 6^{\circ} 04^{\prime} 05^{\prime \prime E}$; 26 Jun 2018; A. Nikolaychuk leg.; mixed pine-birch forest, on sandy road $\bullet 1 \hat{\delta^{\prime}, 1} 1$ ( in copuli); same locality; $57^{\circ} 20^{\prime} 49^{\prime \prime} \mathrm{N}, 66^{\circ} 03^{\prime} 01^{\prime \prime} \mathrm{E} ; 28$ Jun 2018; students leg.; mixed pine-birch forest, on sandy road • 1 ex.; Tyumen

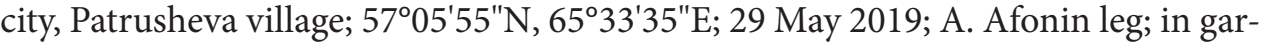
den 1 ex.; Tobolsky district, vicinity of Verkhnie Aremzyany village; 58 $32^{\prime} 93^{\prime \prime} \mathrm{N}$, 6855'04"E; 28 May 2019; E. Sergeeva leg.; mixed birch-aspen-linden forest • 1 ex.; Yarkovsky district, vicinity of lake Petigul'; 57³8'60"N, 68²79'41"E; 19 Jun 2019; T. Khlyzova leg.; birch-aspen forest • 27 ex.; Kazansky district, vicinity of Novoalex-

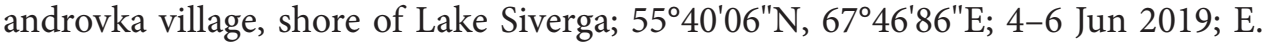
Sergeeva leg; birch forest.

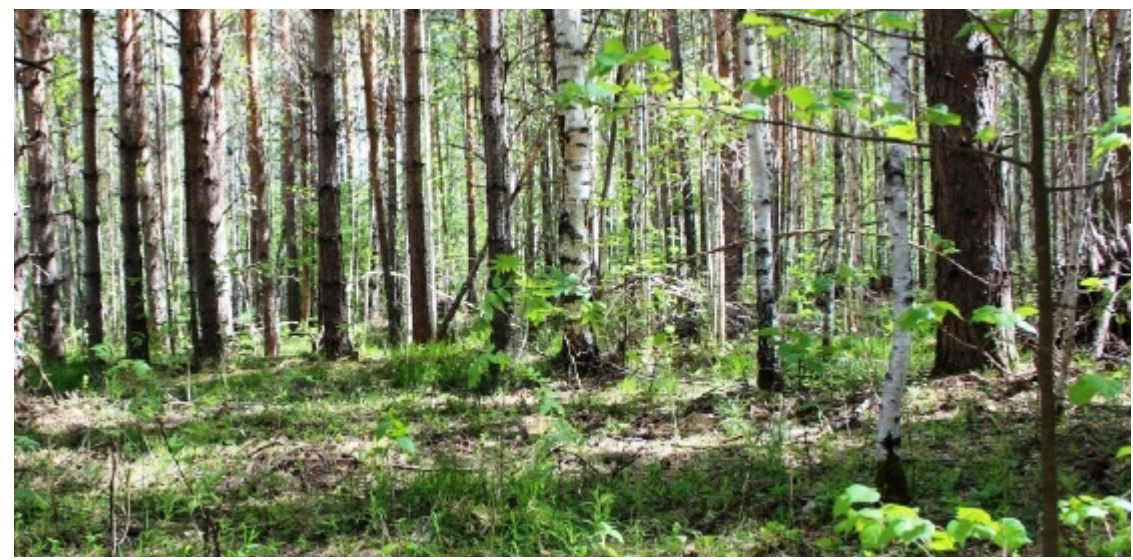

Figure 3. Mixed forest in the subtaiga (Yarkovsky distr.). 


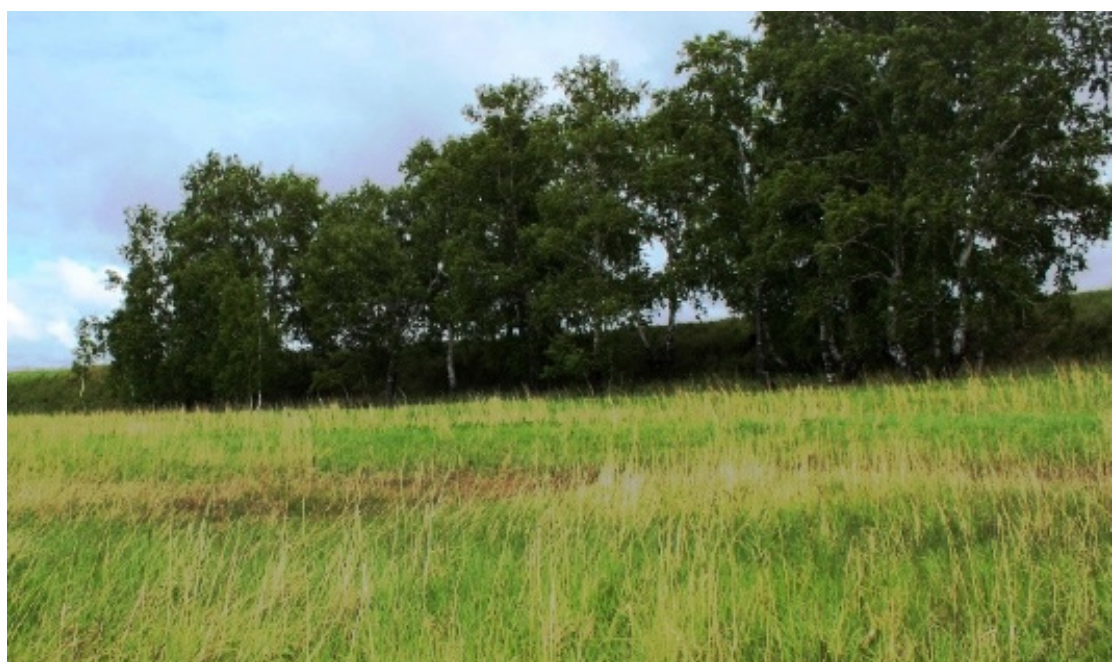

Figure 4. Birch forest in forest-steppe zone (Kazansky distr.).

\section{Discussion}

It is known (Alekseev 2010) that D. quadrimaculata is characterized by natural fluctuations in abundance, which correlate with mass reproduction of its main food object - leaf-eating caterpillars. Therefore, in our opinion, one of the main reasons for species range expansion in Western Siberia is its irruptions and the spread of gypsy moth Lymantria dispar (L.) to the north. Since the end of the XX century, it spread widely in the forest zone of Western Siberia, where its foci were localized before only in the forest-steppe zone (Gninenko 2000; Titkina et al. 2013; Yasyukevich et al. 2013). According to our observations, $L$. dispar reached the highest numbers in 2017-2018. Also, in recent years, another species trophically associated with $L$. dispar - Calosoma sycophanta (L.) has distributed to the north in Western Siberia (Stolbov et al. 2018).

Another possible factors caused the range expansion of the D. quadrimaculata could be the global climate change and adaptation of this species to new habitat conditions. Thus, in recent years, a number of southern invertebrates, new to the region, are actively spreading to the north (Stolbov et al. 2016; Sergeeva and Kapitonov 2017).

The expansion of D. quadrimaculata in the Tyumen region probably occurs from the territory of Kazakhstan (North Kazakhstan region), that is evidenced by the numerous specimen collections of this species in the border areas.

Thus, the appearance of D. quadrimaculata in Tyumen region is apparently associated with three main factors: climate change, irruptions and the range expansion of the main fodder object. 


\section{Acknowledgements}

The work was carried out within the framework of the state research and technology theme "Biodiversity of wetland ecosystems in the South of Western Siberia" (№ 0408-2019-0005; E.V. Sergeeva).

\section{References}

Alekseev VI (2010) Dendroxena quadrimaculata (Scopoli, 1771). In: The Red Data Book of the Kaliningrad Region. Kaliningrad, 104. [in Russian]

Berlov EYa (1977) Necrophagous beetles of the Irkutsk region. In: Fauna and ecology of insects in Eastern Siberia and the Far East. Irkutsk, 71-86. [in Russian]

Efimov DA (2008) Carrion Beetles (Coleoptera, Silphidae) of Kuznetsk-Salair Mountain Area. Proceedings of the Russian Entomological Society 78(2): 59-61. [in Russian]

Gninenko YuI (2000) Some ecological changes in Siberian forests: outbreaks of new species. In:Problems of regional ecology. Materials of the All-Russian Conference, Krasnoyarsk, 174-175. [in Russian]

Ivantsova EA, Vostrikova YuV (2015) Entomophages of unpaired silkworms in the forestagrarian landscapes of the Lower Volga region. Science Almanac 7(9): 970-973. https:// doi.org/10.17117/na.2015.07.970 [in Russian]

Kozminykh VO (1997) Composition of the fauna of the Coleoptera families Silphidae, Sphaeritidae, Histeridae and Dermestidae of the Perm Region. In: Coleoptera of the Urals (Insecta, Coleoptera) 1: 70-89. [in Russian].

Loshchev SM (2015) Entomofauna of the Nature Reserve "Stolby". In: Proceedings of the State Reserve "Stolby”. Krasnoyarsk. 216 pp. [in Russian]

Nikolaev GV, Kozminykh VO (2002) Carrion beetles (Coleoptera: Agyrtidae, Silphidae) of Kazakhstan, Russia and a number of neighboring countries. Almaty. Kazak Universiteti. 158 pp. [in Russian]

Pleshanov AS, Takhteev VV (2008) Refugiums in Baikal Siberia as reserves of unique biodiversity. In: The development of life in the process of abiotic changes on Earth: Materials of the scientific and practical conference, Novosibirsk, 358-370. [in Russian]

Redikortsev VV (1908) Materials to the entomofauna of the Urals. Notes of Ural society of lovers of natural history 27: 95-122. [in Russian]

Rǔžička J (2015) Family Silphidae Latreille, 1807. In: Löbl I, Löbl D (Eds): Catalogue of Palaearctic Coleoptera. Hydrophiloidea-Staphylinoidea. Vol. 2/1. Revised and updated version. Brill, Leiden-Boston, 290-304.

Sergeeva EV, Kapitonov VI (2017) New records of Phaneroptera falcata (Poda, 1761) (Orthoptera, Tettigoniidae) from Tyumenskaya Oblast, Russia. Euroasian Entomological Journal 16(6): 577-578. https://doi.org/10.15298/euroasentj.16.6.10 [in Russian] 
Stolbov VA, Kuzmin IV, Ivanov SA, Kamp J (2016) Expansion of the arthropod areals in Tyumenskaya and Kurganskaya Oblast's of West Siberia, Russia. Euroasian Entomological Journal 15(2): 99-103. [in Russian]

Stolbov VA, Kuzmin IV, Lomakin DE, Ivanov SA, Sitnikov PS (2018) New records and range expansion of Calosoma sycophanta (Linnaeus, 1758) (Coleoptera, Carabidae) in Western Siberia, Russia. Check List 14(5): 731-736. https://doi.org/10.15560/14.5.731

Titkina SN, Popov IO, Semenov SM, Yasjukevich VV (2013) Changes in distribution in Russia and neighboring countries of gipsy moth and nun moth (Lymantria dispar L. and Lymantria monacha L., Lymantriidae, Lepidoptera) due to observed climate change and projected ones for XXI century. The problems of ecological monitoring and modeling of ecosystems 25: 375-394. [in Russian]

Yasyukevich VV, Titkina CN, Davidovich EA, Yasyukevich NV (2013) Changes in boundaries of gipsy moth and nun moth (Lymantria dispar and Lymantria monacha, Lymantriidae, Lepidoptera) ranges due to the global warming: a model approach. Zoologicheskii zhurnal 92 (11): 1377-1382. https://doi.org/10.7868/S0044513413110135 [in Russian] 